\title{
Gebelikte aile içi şiddete maruz kalmanın postpartum depresyon ve maternal bağlanmaya etkisi
}

\section{The effect of exposure to domestic violence during pregnancy on postpartum depression and maternal attachment}

\author{
Ayten TAŞPINAR ${ }^{1 @(D)}$, Seher Sarıkaya KARABUDAK ${ }^{(D)}$, Ayden ÇOBAN $^{1}$ (D), Filiz ADANA ${ }^{2}$ \\ ${ }^{1}$ Aydın Adnan Menderes Üniversitesi, Sağlık Bilimleri Fakültesi, Ebelik Bölümü, 09010, Aydın-Türkiye \\ ${ }^{2}$ Aydın Adnan Menderes Üniversitesi, Hemşirelik Fakültesi, 09010, Aydın-Türkiye
}

Atıf gösterme/Cite this article as: Taşpınar A, Karabudak SS, Çoban A, Adana F. Gebelikte aile içi şiddete maruz kalmanın postpartum depresyon ve maternal bağlanmaya etkisi. ADYÜ Să̆llk Bilimleri Derg. 2021;7(1):94-102. doi:10.30569.adiyamansaglik. 806662

$\ddot{O} \mathbf{z}$

Amaç: Gebelikte aile içi şiddete maruz kalmanın postpartum depresyon ve maternal bağlanmaya etkisini belirlemektir.

Gereç ve Yöntem: Araştırma analitik-kesitsel olarak, Eylül 2016-Haziran 2017 tarihlerinde yapılmıştır. Araştırmanın evrenini 1-4 aylık bebeği olan anneler, örneklemi ise 223 anne oluşturmuştur. Veriler, veri toplama formu, Kadına Yönelik Şiddet Tarama Formu, Maternal Bağlanma Ölçeği (MBÖ) ve Edinburg Postpartum Depresyon Ölçeği ile toplanmıştır.

Bulgular: Kadınların \%14,8'inin gebeliklerinde şiddet türlerinden en az birine maruz kaldıkları, şiddet görenlerin \%13,9'unun sözlü, \%4'ünün fiziksel, \%7,6'sının ekonomik ve \%6,4'ünün cinsel şiddet gördükleri saptanmıştır. Gebeliğinde şiddet görenlerin MBÖ puan ortalamalarının şiddet görmeyenlere göre istatistiksel düzeyde düşük olduğu $(p<0,037)$ ve postpartum depresyon riski yaşadıkları bulunmuştur $(p=0,001)$.

Sonuç: Gebeliğinde şiddet gören kadınların doğum sonrası dönemde maternal bağlanmaları düşük ve depresyon riskleri yüksektir.

Anahtar Kelimeler: Gebelik; Aile İçi Şiddet; Bağlanma; Doğum Sonrası Depresyon.

\begin{abstract}
Aim: To determine the effect of exposure to domestic violence during pregnancy on postpartum depression and maternal attachment.

Materials and Methods: The analytically and crosssectionally research was conducted from September 2016 to June 2017. The population of the study was consisted of mothers with 1-4 months old babies, and the sample was 223 mothers. The data were collected by data collection form, Violence Against Women Screening Form, Maternal Attachment Scale (MAS) and Edinburgh Postpartum Depression Scale.

Results: It was found that $14.8 \%$ of women were exposed to at least one of the types of violence during their pregnancy, $13.9 \%$ of those exposed to violence experienced verbal violence, $4 \%$ physical violence, $7.6 \%$ economic and $6.4 \%$ sexual violence. It was found that the MAS mean scores of those who experienced violence during their pregnancy were statistically lower $(p<0.037)$ compared to those who were not exposed to violence. Women who experienced violence during their pregnancy were at risk of postpartum depression compared to those who did not experience violence $(p=0.001)$.

Conclusion: Women who experienced violence during pregnancy had low maternal attachment in the postpartum period and the risk of depression was high.

Keywords: Pregnancy; Domestic Violence; Attachment; Postpartum Depression.
\end{abstract}

Yazışma Adresi/Address for Correspondence: Ayten TAŞPINAR, Aydın Adnan Menderes Üniversitesi, Sağlık Bilimleri Fakültesi, Ebelik Bölümü, 09010, Aydın-Türkiye, E-mail: aytaspinar@yahoo.com Geliş Tarihi/Received:06.10.2020 Kabul Tarihi/Accepted:11.12.2020

Yayım Tarihi/Published online:23.04.2021 


\section{Giriş}

Kadınlara uygulanan ve kadınları orantısız bir biçimde etkileyen kadına yönelik şiddet, insan hakları ihlali ve kadına yönelik ayrımcılığın bir biçimi olup suç olarak kabul edilmektedir. ${ }^{1-4}$ Yaşamının her döneminde şiddete maruz kalabilen kadın, duygusal ve fiziksel olarak daha hassas olduğu gebelik döneminde de şiddet görebilmektedir. Gebelikte şiddet hem anne hem de fetüs sağlığını olumsuz yönde etkileyen önemli bir halk sağlığı sorunu olup, fiziksel, duygusal, ekonomik ve cinsel şiddet olarak ortaya çıkmaktadır., ${ }^{1,8-8}$ Farklı ülkelerde yapılan çalışmalar gebelerin \%0,9 ile \%49 arasında şiddete maruz kaldıklarını göstermektedir. ${ }^{6,8-}$ 12 Çalışmalar kadınların gebeliklerinde en fazla psikolojik şiddete $(\% 16,6-\% 53,8)$ sonra sirasiyla, cinsel $(\% 3,1-\% 41,8)$ ve fiziksel şiddete $(\% 4,3-\% 21)$ maruz kaldıklarını göstermektedir. ${ }^{9-11} \quad$ Ülkemizde, çeşitli merkezlerde yapilan çalışmalarda, gebeliklerinde kadınların yaygın bir şekilde fiziksel şiddete uğradıkları saptanmış ve gebelikte fiziksel şiddet prevalansı \%4,8$\% 55,1$, duygusal şiddet $\% 26,7$ ile $\% 63,1$; cinsel şiddet $\% 4,4$ ile $\% 36,4$ arasında değişiklik gösterdiği belirlenmiştir. ${ }^{1,13-18}$

Gebelikte şiddet, doğum sonrası annenin ebeveynliği üzerindeki büyük etkisi nedeniyle önemli bir perinatal sağlık sorunudur. Gebelikte şiddet, kadınlarda erken doğuma, düşüğe, kanamalara ve erken membran rüptürüne neden olurken; bebeklerde düşük doğum ağırlığı, kemik kırıkları, yumuşak doku hasarları, akciğer ya da dalak rüptürü ve fetal asfiksi gibi sorunlara yol açabilmektedir. ${ }^{1,2,7,8,19}$ Gebelikte eș șiddetine maruz kalmanın fetal ve neonatal ölüm riskini inceleyen 17 çalışmanın değerlendirildiği bir meta analiz çalışmasında gebelikte eş şiddetine maruz kalmanın fetal ve neonatal ölüm riskini üç kat artırdığı bulunmuştur. ${ }^{20}$ Ayrıca gebeliğinde şiddete maruz kalan annelerin doğum sonrası üç yıl süresince çocuklarına fiziksel şiddet ve ihmal gibi olumsuz ebeveynlik davranışları gösterdikleri bildirilmektedir. Aynı zamanda şiddete maruz kalan gebeler gebelikte ve doğum sonu dönemde depresyon açısından riskli grubu oluşturmaktadırlar. 5, 6, 19,21
Maternal bağlanma, "çocuk ile bakım veren kişi arasında gelişen ilişkide, çocuğun bakım veren kişiyle yakınlık arayışı ile kendini gösteren, özellikle stres durumlarında belirginleşen, tutarlılı̆̆ duygusal bir bă̆" olarak tanımlanmaktadır. Bir annenin bebeğine sevgiyle bağlanması, çocuğun sağlıklı büyüme ve gelişimini sağlayarak daha sonraki bağlanma tecrübeleri için temel oluşturur. Dolayısıyla yaşamın ilk döneminde oluşan güvenli ya da güvensiz bağlanma bir kez belirlendikten sonra yaşam boyunca süreklilik gösterir. ${ }^{22-26}$ Yaşamın ilk yılında, anne-bebek arasında güvenli bağlanma oluşmayan çocuklarda emosyonel, sosyal, fiziksel, zihinsel ve dil gelişimi problemleri gelişebilmekte ve bu çocuklar ihmal ve istismara maruz kalabilmektedirler. Maternal bağlanma süreci gebelik, doğum ve postpartum periyod süresince gelişir ve postpartum periyodu süresince anne-bebek etkileşimi olduğu zaman desteklenir. ${ }^{26,} 27$ Anne-bebek etkileşiminin, annenin ruhsal durumundan da etkilediği bilinmektedir. $\mathrm{Bu}$ duygu durum bozukluklarından bir tanesi de postpartum dönemde ortaya çıkan postpartum depresyondur. Doğum sonu depresyonun bebeğin duygusal, davranışsal ve bilişsel gelişimi ile bağlanma örüntüsü üzerine olumsuz etkiler oluşturduğu gösterilmiştir. ${ }^{19}$, $21,23,28,29$

Ülkemizde gebelerde şiddet sıklığ 1 , postpartum depresyon ve maternal bağlanma ile ilgili konuları ayrı ayrı araştıran pek çok çalışma bulunmaktadır; ancak gebelikte şiddete maruz kalmanın postpartum depresyon ve maternal bağlanmaya etkisini inceleyen kısıtlı sayıda araştırma vardır. Gebelikte şiddete maruz kalmanın postpartum depresyon ve maternal bağlanmaya etkisinin bilinmesi, prenatal ve postnatal dönemlerde planlanan bakım ve izlemin yeniden gözden geçirilmesini sağlayabilir.

$\mathrm{Bu}$ araştırma, gebelikte aile içi şiddete maruz kalmanın postpartum depresyon ve maternal bağlanmaya etkisini incelemek amacı ile yapılmıştır.

Araştırmada aşağıdaki sorulara yanıt aranmıştır. 
1. Gebelikte yaşanan aile içi şiddetin sıklığ1 nedir?

2. Gebelikte yaşanan aile içi şiddetin postpartum depresyon üzerine etkisi nasıldir?

3. Gebelikte yaşanan aile içi şiddetin maternal bağlanma üzerine etkisi nasıldır?

\section{Gereç ve Yöntem}

\section{Araştırmanın tipi}

Araştırma, analitik-kesitsel olarak yapılmıştır.

\section{Araştırmanın evreni ve örneklemi}

Araştırma 1-4 aylık bebeği olan anneler ile Eylül 2016-Haziran 2017 tarihleri arasında, Aydın il merkezinde bulunan aile sağlığ merkezlerinde (ASM) yapılmıştır. Aydın il merkezinde araştırmanın yapıldığı tarihlerde 27 ASM vardır. ASM sayısının fazla olması, ulaşım ve zaman zorluğu nedeniyle basit rastgele örnekleme yöntemiyle 8 ASM araştırmaya alınmıştır. Araştırmanın evrenini, 8 ASM'ine kayitlı 1-4 aylık bebeği olan anneler oluşturmuştur. Örneklem hacminin belirlenmesinde, power (güç) analizinden yararlanılmıştır. Araştırmanın başlangıcında örneklem hacmi hesaplamasına gidilmemiştir. Veriler elde edildikten sonra $(n=233)$ post hock analiz yapılmış ve $\% 95$ olasılıkla $(\alpha=0,05)$, etki gücü $w=0,3$ (orta düzeyde), $\mathrm{Df}=2$ alındığında araştırmanın gücü $\% 98,8$ olarak hesaplanmış ve araştırmanın veri toplama aşaması sonlandırılmıştır. Araştırmaya, bu ASM'lere çocuklarının aşılarını yaptırmak veya muayene için gelen ve 1-4 aylık (29-112 günlük) bebeği olan, en az ilkokul mezunu, bebeği sağlıklı, tek ve doğumdan sonra bebeği sürekli yanında olan, gebeliği süresince eşiyle birlikte yaşayan, miadında doğum yapan, tanı almış ruhsal hastalığı olmayan kadınlar dahil edilmişlerdir. Doğum anomalisi veya doğumdan sonra bebeğinde sağlık problemi olan kadınlar çalışmaya dahil edilmemişlerdir.

\section{Veri toplama araçları}

Çalışmanın verileri, kadınların tanıtıcı özelliklerine ilişkin soruları içeren veri toplama formu, Kadına Yönelik Aile İçi Şiddet Tarama Formu, Edinburg Postpartum
Depresyon Ölçeği ve Maternal Bağlanma Ölçeği ile toplanmıştır.

\section{Veri toplama formu}

Araştırmacılar tarafindan literatür taranarak hazırlanan veri toplama formu; Kadınların, sosyo-demografik (yaş, eğitim durumu, sosyal güvence varlığı, aile tipi, çalışma durumu vb), obstetrik (gebelik sayısı, yaşayan çocuk sayısı vb) özelliklerini, bebeklerine ilişkin özellikleri (bebeğin cinsiyeti, doğum şekli, doğum haftası), eşin gebeliğe ilişkin görüşlerini sorgulayan sorulardan oluşmuştur. ${ }^{1}$, 13-18 Veri toplama formunun kadınlar tarafından anlaşılırlığını belirlemek amacıyla çalışmaya dahil olmayan bir ASM'ye kayıtlı 1-4 aylık bebeği olan 10 kadın ile görüşülmüş ve veri toplama formunu doldurmaları sağlanmıştır. Anlaşılmayan sorular düzenlendikten sonra veri toplama formuna son şekli verilmiştir.

\section{Kadına yönelik aile içi şiddet tarama formu}

Sağlık Bakanlığı tarafından Aile Sağlığ Merkezlerinde 15 yaş üzeri kadınlarda kadına yönelik şiddeti taramaya yönelik kullanılması önerilen ve kadınların son bir yıl içinde ve son bir ay içinde aile içi şiddete maruziyetlerini değerlendiren toplam 9 sorudan oluşan bir formdur. Bu formla sözel, fiziksel, ekonomik ve cinsel şiddet sorgulanmaktadır. Sorulara verilen "evet" yanıtı şiddetin varlığını göstermektedir. Son bir y1l sorgulayan form olması nedeniyle kadınların gebeliklerinde gördükleri şiddetin sorgulanmış olduğu kabul edilmiştir. ${ }^{30}$

\section{Edinburg postpartum depresyon ölçeği}

Cox ve ark. tarafindan (1987) geliştirilen, Engindeniz ve arkadaşları tarafından Türkçe geçerlilik ve güvenilirliği yapılan ölçek, doğum sonrası dönemde depresyon riskini belirlemektedir. $^{31,} 32$ Tarama amaçlı olarak hazırlanmış olup, depresyon tanısı koymaya yönelik kullanılmamaktadır. Ölçek, kendini değerlendirme türünde dörtlü likert tipindedir ve 10 maddeden oluşmaktadır. Ölçekte ters yönlü 7 madde bulunmaktadır $(3,5,6,7,8,9$ ve 10. maddeler). Ölçeğin toplam puanı bu madde puanlarının toplanması ile elde edilir ve alınabilecek puan 0-30 arasında değişmektedir. Ölçeğin kesme puanının 12, 
Cronbach's alfa güvenirlik katsayısının 0,79 olduğu belirlenmiştir. Kesme noktası olarak 12 ve üzerindeki skorlar yüksek depresyon riskini göstermektedir. ${ }^{32}$

\section{Maternal bağlanma ölçeği}

Maternal Bağlanma Ölçeği (MBÖ), maternal sevgiyle bağlanmayı ölçmek amaciyla, Mary E. Muller tarafindan 1994 yılında geliştirilmiştir. Sevgiyi gösteren maternal duygu ve davranışları ölçen MBÖ kişinin kendinin uyguladığı bir ölçek olduğu için, okuma-yazma bilen ve okuduğunu anlayabilen kadınlarla uygulanabilen bir ölçektir. Her bir madde "her zaman" ile "hiçbir zaman" arasında değişen, 4'lü likert tipi 26 maddelik bir ölçektir. Her madde doğrudan ifadeleri içermektedir ve Her zaman $(\mathrm{a})=4$ puan, Sik sik $(\mathrm{b})=3$ puan, Bazen $(\mathrm{c})=2$ puan ve Hiçbir zaman $(\mathrm{d})=1$ puan olarak hesaplanır. Ölçekten elde edilecek en düşük puan 26, en yüksek puan 104 arasında değişmektedir. Ölçekten elde edilen toplam puanın artması, annelerde maternal bağlanmanın arttığını göstermektedir. Maternal Bağlanma Ölçeği'nin, Türkçe formunun geçerlilik ve güvenirlik çalışması, Kavlak ve Şirin tarafından yapılmıştır. Ölçeğin Cronbach's alfa güvenirlik katsayısının 0,82 olduğu belirlenmiştir. ${ }^{22}$

Araştırmaya dahil edilme kriterlerine uygun kadınlara çalışma konusunda bilgi verilmiş ve veri toplama formlarını doldurmaları için kendilerini güvenli ve rahat hissedecekleri bir odaya (ebe eğitim odası, emzirme odası gibi) geçilmiştir. Veri toplama formu araştırmacilar tarafından yüz yüze görüşülerek doldurulmuştur. Kadına Yönelik Aile İçi Şiddet Tarama Formu, Edinburg Postpartum Depresyon Ölçeği ve Maternal Bağlanma Ölçeği özbildirim yoluyla kadınlar tarafından doldurulmuştur. Veri toplama formlarının doldurulması yaklaşı 15-20 dakika sürmüştür.

\section{Verilerin analizi}

Araştırmadan elde edilen verilerin analizi istatistik paket programı Statistical Package for the Social Sciences (SPSS) 25,0 kullanılarak yapılmıştır. Veri normal dağılıma uygunlukları Shapiro Wilk testi ile değerlendirilmiştir. Tanımlayıcı veriler yüzdelik, aritmetik ortalama, standart sapma ile gösterilmiştir. Kategorik verilerin karşılaştırılmasında Pearson chi-square ve Fisher Exact testleri, bağımsız grupların gruplar arası karşılaştırılmasında ise Student $t$ ve Mann Whitney $U$ testleri ve nicel değişkenler arası ilişkilerin değerlendirilmesinde Pearson Korelasyon analizi kullanılmıştır. Sonuçlar \%95'lik güven aralığında anlamlılık $p<0,05$ düzeyinde değerlendirilmiştir.

\section{Araştırmanın etik boyutu}

Araştırmanın yapılabilmesi için ilgili üniversitenin Tip Fakültesi Etik Kurulu'ndan etik kurul izni (Protokol No: 2016/882) ve araştırmanın yürütüldüğü kurumdan yazılı izin alınmıştır. Maternal Bağlanma Ölçeğinin kullanımı için yazarlardan sözlü izin alınmıştır. Ayrıca çalışmanın yürütülmesinde Helsinki Bildirgesi ilkelerine uyulmuştur.

\section{Bulgular}

Tablo 1'de kadınların sosyodemografik ve obstetrik özellikleri verilmiştir. Kadınların $\% 61$ 'inin 25-34 yaş grubunda oldukları, $\% 57,4$ 'ünün lise/üniversite mezunu olduğu, $\% 13,9$ 'unun sosyal güvencesinin olmadığ \%78'inin çekirdek aile tipinde yaşadıkları, sadece \%34,1'inin çalıştığ 1 ve \%64'ünün 1-7 yıllık evli oldukları saptanmıştır. Katılımcıların \%57,8'inin 2-5 arası yaşayan çocuğu, \%44,4'ünün bebeklerinin 29-57 günlük olduğu, $\% 58,3$ 'ünün son doğumlarında çocuklarının cinsiyetinin kız olduğu, \%62,8'inin vajinal yolla doğum yaptığı bulunmuştur. Kadınlara, ilk sırada eş $(\% 56,3)$ ikinci sırada kayınvalide/kayınpeder $(\% 27,3)$, daha sonra anne/baba/kardeş $(\% 9,1)$ ve görümce/elti/kayınbirader $\quad(\% 7,3)$ tarafindan şiddet uygulandığı bulunmuştur (Tablo 1).

Tablo 2'de kadınların gebeliklerinde gördükleri şiddet çeşitleri ve şiddet çeşitlerine göre MBÖ puan ortalamaları ve postpartum depresyon risk durumları verilmiştir. Gebelikleri süresince eşi veya aile üyeleri tarafından şiddet görüp görmedikleri sorulan kadınların \%13,9'unun $(\mathrm{n}=31)$ sözlü şiddet, \%4'ünün $(\mathrm{n}=9)$ fiziksel şiddet, \%7,6'sının $(\mathrm{n}=17)$ ekonomik şiddet, \%6,7'sinin cinsel şiddet gördükleri saptanmıştır. $\mathrm{Bu}$ şiddet 
türlerinden en az birine maruz kalmayı "gebelikte şiddete maruz kalma" olarak tanımlanmış olup gebelikte şiddete maruz kalan kadınların oranı \%14,8 (n=33)'dir.

Tablo 1. Kadınların sosyodemografik ve obstetrik özellikleri $(n=223)$.

\begin{tabular}{|c|c|c|}
\hline Özellikler & Sayı & $\%$ \\
\hline \multicolumn{3}{|l|}{ Yaş grubu } \\
\hline $19-24$ & 41 & 18,4 \\
\hline $25-34$ & 136 & 61,0 \\
\hline $35-42$ & 46 & 20,6 \\
\hline \multicolumn{3}{|l|}{ Eğitim Durumu } \\
\hline İlkokul/ortaokul mezunu & 95 & 42,6 \\
\hline Lise/üniversite mezunu & 128 & 57,4 \\
\hline \multicolumn{3}{|l|}{ Sosyal Güvence } \\
\hline Yok & 31 & 13,9 \\
\hline \multicolumn{3}{|l|}{ Aile Tipi } \\
\hline Çekirdek & 174 & 78,0 \\
\hline Geniş & 49 & 22,0 \\
\hline \multicolumn{3}{|l|}{ Çalışma Durumu } \\
\hline Evet & 76 & 34,1 \\
\hline \multicolumn{3}{|l|}{ Evlilik süresi (yıl) } \\
\hline $1-7$ & 135 & 64,0 \\
\hline $8-23$ & 76 & 36,0 \\
\hline \multicolumn{3}{|l|}{ Yaşayan çocuk sayısı } \\
\hline 1 & 94 & 42,2 \\
\hline $2-5$ & 129 & 57,8 \\
\hline \multicolumn{3}{|l|}{ Bebeğin yaşı (gün) } \\
\hline $29-57$ & 99 & 44,4 \\
\hline $58-85$ & 62 & 27,8 \\
\hline $86-112$ & 62 & 27,8 \\
\hline \multicolumn{3}{|l|}{ Bebeğin cinsiyeti } \\
\hline $\mathrm{K} 1 \mathrm{z}$ & 130 & 58,3 \\
\hline Erkek & 93 & 41,7 \\
\hline \multicolumn{3}{|l|}{ Doğum șekli } \\
\hline Vajinal & 140 & 62,8 \\
\hline Sezaryen & 83 & 37,2 \\
\hline Yaş ortalaması $\pm \mathrm{SS}$ & \multicolumn{2}{|c|}{$29,59 \pm 5,676(19-42)$} \\
\hline Evlilik yılı ortalamas \pm SS & \multicolumn{2}{|c|}{$6,94 \pm 5,45(1-23)$} \\
\hline Gebelik sayısı ortalamas $1 \pm \mathrm{SS}$ & \multicolumn{2}{|c|}{$2,25 \pm 1,20(1-6)$} \\
\hline Yaşayan çocuk sayısı ortalaması $\pm S S$ & \multicolumn{2}{|c|}{$1,92 \pm 0,97(1-5)$} \\
\hline \multicolumn{3}{|l|}{ Şiddeti uygulayan kişi $(\mathrm{n}=55)^{*}$} \\
\hline Eş & 31 & 56,3 \\
\hline Kayınvalide/Kayınpeder & 15 & 27,3 \\
\hline Anne/baba/kardeş & 5 & 9,1 \\
\hline Görümce/elti/kayınbirader & 4 & 7,3 \\
\hline
\end{tabular}

Gebeliğinde sözlü $(95,74 \pm 14,48)$, ekonomik $(92,41 \pm 17,96)$ ve cinsel $(93,86 \pm 13,09)$ şiddet gördüğünü belirten kadınların bu şiddet türlerini görmeyenlere (sirasiyla $101,63 \pm 3,81 ; \quad 101,50 \pm 4,15$ ve $101,31 \pm 5,74)$ göre MBÖ puan ortalamalarının daha düşük olduğu saptanmış olup bu farkın istatistiksel olarak da anlamlı olduğu bulunmuştur (sırasıyla; $p=0,001 ; p=0,018$ ve $p=0,021)$. Ayrıca, gebeliklerinde şiddet gören (en az bir çeşit şiddet türüne maruz kalan)
Katılımcıların \%11,5’i (n=26) gebeliğinden önce de şiddet gördüğünü belirtmişlerdir (Tablo 2). 
Tablo 2. Kadınların gebeliklerinde gördükleri şiddet çeşitlerine göre MBÖ puan ortalamaları ve postpartum depresyon risk durumları $(\mathrm{n}=223)$.

\begin{tabular}{|c|c|c|c|c|c|c|c|c|}
\hline \multirow[t]{2}{*}{ Şiddet Çeşitleri } & & \multirow[t]{2}{*}{$\mathrm{n}$} & \multirow[t]{2}{*}{$\%$} & MBÖ & \multirow[t]{2}{*}{$p$} & $\begin{array}{l}\text { Depresyon } \\
\text { riski var } \\
12 \leq\end{array}$ & $\begin{array}{l}\text { Depresyon } \\
\text { riski yok } \\
12<\end{array}$ & \multirow[t]{2}{*}{$p$} \\
\hline & & & & $\mathbf{X} \pm \mathrm{SS}$ & & $\mathrm{n}(\%)$ & $\mathrm{n}(\%)$ & \\
\hline \multirow[t]{2}{*}{ Sözlü Şiddet } & Var & 31 & 13,9 & $95,74 \pm 14,48$ & $0,001^{*}$ & $21(67,7)$ & $10(32,3)$ & $0,001^{* * * *}$ \\
\hline & Yok & 192 & 86,1 & $101,63 \pm 3,81$ & & $7(3,6)$ & $185(96,4)$ & \\
\hline \multirow[t]{2}{*}{ Fiziksel Şiddet } & Var & 9 & 4,0 & $100,00 \pm 4,12$ & $0,295^{* * *}$ & $8(88,9)$ & $1(11,1)$ & - \\
\hline & Yok & 214 & 96,0 & $100,85 \pm 6,80$ & & $20(9,3)$ & $194(90,7)$ & \\
\hline \multirow[t]{2}{*}{ Ekonomik Şiddet } & Var & 17 & 7,6 & $92,41 \pm 17,96$ & $0,018^{* * *}$ & $9(52,9)$ & $8(47,1)$ & $0,001^{\text {**** }}$ \\
\hline & Yok & 206 & 92,4 & $101,50 \pm 4,15$ & & $19(9,2)$ & $187(90,8)$ & \\
\hline \multirow{2}{*}{ Cinsel Şiddet } & Var & 15 & 6,7 & $93,86 \pm 13,09$ & $0,021^{* * *}$ & $12(80,0)$ & $3(20,0)$ & $0,001^{* * * *}$ \\
\hline & Yok & 208 & 93,3 & $101,31 \pm 5,74$ & & $16(7,7)$ & $192(92,3)$ & \\
\hline \multirow{2}{*}{$\begin{array}{l}\text { Genel Şiddet } \\
\text { (en az birine maruz } \\
\text { kalan) }\end{array}$} & Var & 33 & 14,8 & $96,21 \pm 14,15$ & $0,037^{*}$ & $21(63,6)$ & $12(36,4)$ & $0,001^{* * * *}$ \\
\hline & Yok & 190 & 85,2 & $101,61 \pm 3,82$ & & $7(3,7)$ & $183(96,3)$ & \\
\hline \multirow{2}{*}{$\begin{array}{l}\text { Gebelik } \\
\text { Şiddet }\end{array}$} & Var & 26 & 11,7 & $95,42 \pm 15,71$ & $0,165^{* * *}$ & $18(69,2)$ & $8(30,8)$ & $0,001^{* * * *}$ \\
\hline & Yok & 197 & 88,3 & $101,52 \pm 3,89$ & & $10(5,1)$ & $187(94,9)$ & \\
\hline
\end{tabular}

Kadınların depresyon risk durumları değerlendirildiğinde, gebeliğinde şiddet görenlerin depresyon risklerinin görmeyenlere oranla oldukça yüksek olduğu (sırasıyla sözlü $\% 67,7$ 'ye $\% 3,6$; ekonomik \%52,9'a \%9,2 ve cinsel şiddet \%80'e \%7,7) bulunmuştur $(p=0,001) . \mathrm{Bu}$ şiddet türlerinden en az birini yaşayan kadınların \%63,6'sının şiddet yaşamayanların ise \%3,7'sinin depresyon riski yaşadığı ve gebelik öncesi şiddet gören kadınların depresyon riskinin $(\% 69,2)$, şiddet görmeyenlere $(\% 5,1)$ oranla oldukça yüksek olduğu ve bu farkın istatistiksel olarak anlamlı olduğu bulunmuştur $(p=0,001)$, (Tablo 2). Kadınların depresyon puanları ile maternal bağlanma puanları arasında hafif düzeyde, negatif yönde bir ilişki olduğu saptanmıştır (r:-0,277; $p=0,000)$.

\section{Tartışma}

Gebelikte aile içi şiddete maruz kalmanın postpartum depresyon ve maternal bağlanmaya etkisini incelemek amacı ile 1-4 aylık bebeği olan kadınlarla yürütülen araştırmada kadınların \%14,8'inin gebelik sürecinde şiddet türlerinden birine eşi veya aile üyeleri tarafından maruz kaldıkları saptanmıştır. Şiddet gören kadınların şiddet türlerinden en fazla sözlü $(\% 13,9)$ şiddete maruz kaldıkları, daha sonra sirasiyla ekonomik $(\% 7,6)$, cinsel $(\% 6,7)$ ve fiziksel (\%4) şiddet gördükleri saptanmıştır. Şiddetin en fazla eş $(\% 57,7)$, kayınvalide $(\% 17,4)$ ve kayınpeder $(\% 11,6)$ tarafından uygulandığ 1 saptanmıştır. Dünyada gelişmiş ya da gelişmekte olan ülkelerde yapılan çalışmalarda gebelikte yaşanan şiddet oranlarının \%1-\%49 arasında değiştiği saptanmıştır. ${ }^{6}$, 8-12 Afrika'da yapılan bir çalışmada gebelerin \%21,5'inin şiddet türlerinden en az birine maruz kaldığ $\% 8,7$ 'sinin fiziksel, \%3,1'inin cinsel, $\% 16,6$ 'sının psikolojik şiddet gördükleri belirlenmiştir. ${ }^{9}$ Gebelerle yapılan diğer bir çalışmada da gebelikte eş şiddeti prevalansı $\% 41,1$ olarak saptanmış psikolojik, fiziksel ve cinsel şiddet prevalansları sirasiyla \%29,1, $\% 21, \% 19,8$ bulunmuştur. ${ }^{11}$

Ülkemizde yapılan çalışmalarda kadınların gebelikte fiziksel şiddete $\% 4,8$ ile $\% 36,4$, duygusal şiddete $\% 26,7$ ile $\% 99,1$, ekonomik şiddete $\% 28,2$ ile $\% 31,7$ ve cinsel şiddete $\% 5,4$ ile $\% 32,5$ oranları arasinda maruz kaldıkları görülmüştür. 2, 3, 14, 15, 17 Şiddet türlerinden en az birine maruz kalan gebe oranının ise \%20-\%71,4 arasında olduğu bulunmuştur. ${ }^{1,14,33}$

Gebelikte şiddete ilişkin yapılan çalışmalarda da gebelerin en çok duygusal ve sözel şiddete maruz kaldıkları, en düşük ise fiziksel şiddet yaşadıkları bildirilmiştir. ${ }^{2,14,15}$, 17 Çalışmamızda kadınların maruz kaldıkları şiddet sıklığı ile diğer çalışmalardaki şiddet sıklığı arasındaki farklılıkların çalışmalarda kullanılan metoda, örneklem sayısına, çalışmanın yapıldığ 1 yere ve kültüre göre değiştiği düşünülmüştür. Sonuç olarak hem ülkemizde hem de diğer ülkelerde yapılan çalışmalarda kadınların yaygın olarak 
gebeliklerinde de şiddet gördükleri saptanmıştır. Kadınların gebeliklerinde fiziksel şiddete daha düşük oranda maruz kalmaları, şiddet uygulayıcılarının fetüse zarar vermeye yönelik çekincelerinden kaynaklanmış olabilir. Sözel şiddetin daha fazla bulunması da, gebelikte fiziksel şiddet olarak uygulanamayan davranışların sözel şiddet olarak ortaya çıktı̆̆ 1 şeklinde yorumlanabilir. Çalışmamızda gebelerin gebeliklerinden önce de şiddet görme oranı $\% 11,7$ olup gebeliklerinden önce şiddet görenlerin tamamının gebeliklerine şiddet görmeye devam ettikleri, gebelik öncesi şiddet görmeyen kadınların \%3,6'sının gebeliklerinde şiddet gördüğü saptanmıştır. Çalışma bulgularımız gebeliğin kadını şiddetten korumadığını göstermektedir.

Gebeliğinde sözlü, ekonomik ve cinsel şiddet gören kadınların şiddet görmeyen kadınlara göre MBÖ puan ortalamalarının istatistiksel düzeyde düşük olduğu saptanmıştır. Doğum sonrası gerçekleşen maternal bağlanma bebeklerin sağliklı bir şekilde büyümelerini ve gelişmelerini sağlayarak ileriki yaşamlarında da sağlıklı bir şekilde hayatlarını sürdürmelerini sağlayacaktır. Eğer anne ile bebek arasında yaşamın ilk yılında güvenli bağlanmayı başarmada gerekli koşullar karşılanamazsa, bebek emosyonel, sosyal, fiziksel, zihinsel ve dil gelişimi problemleri yaşar. Maternal bağlanmada başarısızlıkların yaşandığı durumlarda bebek ihmal ve istismar açısından risk altındadır. Anne-bebek bağlanma süreci gebelik, doğum ve postpartum periyodu süresince gelişir ve postpartum periyodu süresince anne-bebek etkileşimi olduğu zaman desteklenir. ${ }^{26,27,34}$ Çalışmamızda kadınların gebeliklerinde sözlü, ekonomik ve cinsel şiddet görmelerinin de maternal bağlanmayı olumsuz etkilediğinin bulunması, kadınların gebeliklerinden önce ve gebeliklerinde şiddet yönünden taranmalarını, gerekli bakım ve desteğin zamanında sağlanmasının önemini ortaya koyması bakımından önemlidir.

Çalışmada gebeliğinde sözlü, ekonomik ve cinsel şiddet gören kadınların şiddet görmeyenlere göre depresyon riski altında oldukları (sirasıyla $\% 67,7 ; \% 52,9$ ve $\% 80$ ) bulunmuştur. $\mathrm{Bu}$ şiddet türlerinden en az birini yaşayan kadınların \%63,6'sının, şiddet yaşamayanların ise \%3,7'sinin depresyon riski yaşadığı ve bu farkın da istatistiksel olarak ileri derecede anlamlı olduğu saptanmıştır. Çin'de yapılan bir çalışmada gebeliğinde şiddet gören kadınların \%25,1'nin postpartum depresyon yaşadıkları, diğer bir araştırmada ise gebelikte aile içi şiddet gören kadınların \%60'ının postpartum depresyon yaşadıkları bulunmuştur. ${ }^{35,36}$ Manisa'da yapılan çalışmada ise gebelikte aile içi şiddet gören kadınların \%50,5'inde postpartum depresyon bulunmuştur. ${ }^{3}$ Anne-bebek etkileşiminin, annenin ruhsal durumundan etkilendiği bilinmektedir. Çalışmamızda postpartum depresyon puanı arttıkça maternal bağlanma puanlarının düştüğü de saptanmıştır. Postpartum depresyon, anneçocuk etkileşimini bozabilmekte, güvensiz bağlanmaya, etkilenen çocuklarda gelişimde gecikme ve sosyal etkileşimde zorlanmaya yol açabilmektedir. ${ }^{23,28,29}$ Yaşamın hangi döneminde olursa olsun şiddet gören kadınlarda anksiyete, depresyon, psikoz, travma sonrası stres bozukluğu ve yeme bozukluğu gibi birçok psikiyatrik rahatsızlıkların görülme riskinin $\operatorname{arttığg}^{37}$ göz önüne alınırsa gebeliğinde şiddet gören kadınların postpartum depresyon riskinin yüksek olması kaçınılmazdır. Çalışmamızda gebeliğinde şiddet gören kadınların görmeyenlere göre istatistiksel düzeyde depresyon puanlarının yükssek çıkması gebelikte şiddet görmenin postpartum depresyon için bir risk faktörü olduğunu ortaya koymaktadır. Anne ve çocuk sağlığının korunması ve yükseltilmesi için kadınların gebelik ve postpartum dönemlerinde şiddet yönünden taranmaları, şiddet görenlere uygun ve nitelikli bakımın ve desteğin sağlanması önerilebilir.

\section{Araştırmanın sınırlılıkları}

Araştırmanın sınırlılıkları ölçüm araçları ile sinırlidir.

\section{Sonuç}

Sonuç olarak; gebeliğinde şiddet gören kadınların postpartum dönemde maternal bağlanmalarının düşük ve depresyon risklerinin yüksek olduğu bulunmuştur. 
Araştırma sonuçları doğrultusunda; gebelik ve doğum sonrası şiddetin ve sağlık üzerine etkilerinin azaltılması, siddetin sürekliliğinin önlenmesi, koruyucu önlemlerin alınması için sağlık profesyonellerinin, rutin olarak perinatal ziyaretleri gerçekleștirmesi ve bu ziyaretlerde şiddet tarama aracı kullanmaları, şiddetin saptanması durumunda, kadın ve çocuk sağlığını korumaya yönelik eğitim, rehberlik ve danışmanlık hizmetlerinin planlanması ve yürütülmesi, hemşirelerin ve ebelerin doğum sonrası dönemde anne-bebek bağlılığını etkileyebilecek, depresyon riskini artırabilecek gebelikte şiddet ve diğer risk faktörlerini prenatal dönemde belirleyerek, doğum sonu döneme yönelik eğitim ve danışmanlık yapmaları ve kadınları desteklemeleri önerilmektedir.

\section{Araştırmanın Etik Boyutu}

Araştırmanın yapılabilmesi için ilgili üniversitenin Tıp Fakültesi Etik Kurulu'ndan etik kurul izni (Protokol No: 2016/882) ve araştırmanın yürütüldüğü kurumdan yazılı izin alınmıştır. Maternal Bağlanma Ölçeğinin kullanımı için yazarlardan sözlü izin alınmıştır. Ayrıca çalışmanın yürütülmesinde Helsinki Bildirgesi ilkelerine uyulmuştur.

\section{Bilgilendirilmiş Onam}

\begin{tabular}{lccc}
\multicolumn{1}{c}{ Araştırmaya dahil edilen } & kadınlara \\
araştırmanın başında & bilgi & verilerek \\
bilgilendirilmiş onamları alınmıştır. &
\end{tabular}

\section{Yazar Katkıları}

Fikir: A.T. Tasarım: A.T, A.Ç. Verilerin toplanması ve işlemesi: A.T., S.S.K. Analiz ve yorum: F.A. Literatür taramasi: A.T., S.S.K, A.Ç. Makale yazımı: A.T. Eleştirel inceleme: S.S.K., A.Ç. ve F.A.

\section{Çıkar Çatışması Beyanı}

Makalenin yazarları arasında herhangi bir kişisel ve finansal çıkar çatışması bulunmamaktadir.

\section{Araştırma Desteği}

$\mathrm{Bu}$ çalışma Aydın Adnan Menderes Üniversitesi Bilimsel Araştırma Projeleri Birimi tarafindan HF-18004 proje numaras1 ile desteklenmiştir.

\section{Beyanlar}

$\mathrm{Bu}$ çalışma 18-19 Ekim 2019 tarihleri arasında düzenlenen 2. Uluslararası Tarım, Çevre ve Sağlık Kongresi'nde sözlü bildiri olarak sunulmuştur.

\section{Hakem Değerlendirmesi}

Dış bağımsız

\section{Kaynaklar}

1. Taşpınar A, Bolsoy B, F. Kaya, A. Şirin, G. Şirin, Physical violence and affecting factors during pregnancy in Çanakkale. Aile ve Toplum Dergisi. 2008; 4(13): 63-76.

2. Güler N. Gebelikte eşi tarafindan kadına uygulanan fiziksel, duygusal, cinsel ve ekonomik șiddet ve ilişkili faktörler. DEUHYO ED. 2010; 3(2): 72-77.

3. Muslu A. Gebelikte Aile İçi Şiddet ve Postpartum Depresyon İlişkisi; Manisa Örneği. [Yüksek lisans Tezi]. Manisa, Türkiye; Celal Bayar Üniversitesi; 2014.

4. World Health Organization. Guidelines Approved by the Guidelines Review Committee, Responding to Intimate Partner Violence and Sexual Violence Against Women. WHO Clinical and Policy Guidelines 2013.

5. Eman A, El-Hosary EA, Abd-Elsalam A, Emaghawry Eldeeb AM. Effect of violence on pregnancy domestic outcomes among rural and urban women. Journal of Nursing and Health Science. 2017; 6( 3): 35-42.

6. Kita S, Yaeko K, Porter SE. Prevalence and risk factors of intimate partner violence among pregnant women in Japan. Health Care for Women International. 2014; 35: 442-457.

7. Topatan S, Koç E, Karakaya N, Mumcu N. Gebelikte yaşanan aile içi şiddetin doğasının incelenmesi: nitel bir çalıșma. Düzce Üniversitesi Sağlık Bilimleri Enstitüsü Dergisi. 2020; 10(1): 435.

8. Valladares E, Pena R, Persson LA, Hogberg U. Violence against pregnant women: prevalence and characteristics. A population- based study in Nicaragua. An International Journal of Obstetrics and Gynaecology. 2005; 112(9): 1243-8.

9. Groves AK, Mc Naughton-Reyes L, Martin SL, Foshee V, Maman S. Prevalence, rates and correlates of intimate partner violence among South African women during pregnancy and the postpartum period. Matern Child Health J. 2015; 19(3): 487-95.

10. Gurung S, Acharya J. Gender-based violence among pregnant women of syangja district, Nepal. Osong Public Health Res Perspect. 2016; 7(2): 101-107.

11. Azene ZN, Yeshita HY, Mekonnen FA. Intimate partner violence and associated factors among pregnant women attending antenatal care service in Debre Markos town health facilities, Northwest Ethiopia. PLoS ONE. 2019; 14(7): e0218722.

12. World Health Organization. Intimate Partner Violence During Pregnancy. Geneva: 2012. 23 Ağustos 2020 http://whqlibdoc.who.int/hq/2011/WHO RHR 11.35 eng.pdf. Accessed August 3, 2020.

13. Arslantaş H, Adana F, Ergin F, et al. Domestic violence during pregnancy in an eastern city of Turkey: A field study. $J$ Interpers Violence. 2012; 27(7): 1293-313.

14. Giray H, Keskinoğlu P, Sönmez Y, et al. Domestic violence and associations during pregnancy. Sürekli Tip Eğitimi Dergisi. 2005; 10: 217-220.

15. Karaoğlu L, Celbis O, Ercan C, et al. Physical, emotional and sexual violence during pregnancy in Malatya, Turkey. Eur $J$ Public Health. 2005; 16(2): 149-156.

16. Taşpınar A, Bolsoy N, Şirin, A. Gebeler fiziksel şiddete uğruyorlar mı? Manisa örneği. Adli Psikiyatri Dergisi. 2005; 2: 41-47.

17. Sağkal T, Kalkım A, Uğurlu AS, Kırmızılar NE. Gebelerin eși tarafından şiddete maruz kalma durumları ve şiddetle ilişkili faktörlerin incelenmesi. TAF Prev Med Bull. 2014; 13(5): 381390.

18. Demirel Bozkurt Ö, Daşıkan Z. Gebelikte eş şiddeti: risk faktörleri, sağlık sonuçları ve tarama araçları. Türkiye Klinikleri J Obstet Womens Health Dis Nurs Special Topics. 2016; 2(2): 15-22. 17. 
19. Bacchus L, Mezey G, Bewley S. Domestic violence: prevalance in pregnant women and associations with physical and psychological health. Europen Journal of Obstetrics \& Gynecology and Reproductive Biology. 2004;113: 6-11.

20. Pasto-Moreno G, Ruiz-Perez I, Henares-Montiel J, Petrova D. Intimate partner violence during pregnancy and risk of fetal and neonatal death: a meta-analysis with socieconomic contex indicators. American Journal of Obstetrics \& Gynecology. 2020; 222 (2): 123-133.e5.

21. Tiwari A, Chan KL, Fong D et al. The impact of psychological abuse by an intimate partner on the mental health of pregnant women. An International Journal of Obstetrics and Gynaecology. 2008; 115(3): 377-384.

22. Kavlak O, Şirin A. Maternal bağlanma ölçeğinin Türk toplumuna uyarlanması. Uluslararası İnsan Bilimleri Dergisi. 2009; 6(1): 190-202.

23. Öztürk R, Saruhan A. 1-4 Aylık premature bebeği hastanede tedavi gören annelerin depresyon ve maternal bağlanma iliş̧sisinin incelenmesi. Hemşirelikte Araştırma Geliş̧tirme Dergisi. 2013;1: 32-47.

24. Sabuncuoğlu O, Berkem M. Relationship between attachment style and depressive symptoms in postpartum women: Findings from Turkey. Turk Psikiyatri Derg. 2006; 17(4): 252-258.

25. Akkoca Y. Doğum Sonrasında Anne-Bebek Bağlanmasını Etkileyen Faktörler [Uzmanlık Tezi]. Ankara, Türkiye: Gazi Üniversitesi; 2009.

26. Kavlak O, Şirin A. Anne ve babaya ait bağlanma ve hemşirenin sorumlulukları. Ege Üniversitesi Hemşirelik Yüksekokulu Dergisi. 2007; 23(2): 183-194.

27. Kesebir S, Kavzoğlu ÖS, Üstündağ FM. Attachment and psychopathology. Psikiyatride Güncel Yaklaşımlar. 2011; 3(2): 321-342.

28. Bergström BE, Wallin L, Thomson G, Flacking R. Postpartum depression in mothers of infants cared for in a neonatal intensive care unit incidence and associated factors. J Neonatal Nurs. 2011; 18(4): 143-151.

29. Korja R, Savonlahti E, Haataja L, et al. Attachment representations in mothers of preterm infants. Infant Behav Dev. 2009; 32(3): 305-311.

30. Kırıkkale Sağlık Müdürlüğü. Kadına Yönelik Aile İçi Şiddet Tarama Formu. https://kirklareliism.saglik.gov.tr/TR,117439/dokumanlar.html 10 Temmuz 2016'da erişildi.

31. Cox JL, Holden JM. Detection of postnatal depression: Development of the 10-item Edinburgh Postnatal Depression Scale (EPDS). Br JPsychiatry. 1987; 150(6): 782-6.

32. Engindeniz AN, Küey L, Kültür S. Validated Turkish version of Edinburgh Postpartum Depression Scale. Bahar Sempozyumları 1 Kitabı. Ankara: Psikiyatri Derneği Yayınları. 1996: 51-52.

33. Göğüş, T, Yıldız, H. Trimestırlara göre gebelerde şiddet yaşama durumu, etkileyen faktörler ve perinatal sonuçlar. TAF Prev Med Bull. 2013; 12(6): 657-664.

34. Keskin F. Doğum Şekli ve Maternal Bağlanmaya Etki Eden Faktörlerin İncelenmesi [Yüksek lisans Tezi]. Malatya, Türkiye: İnönü Üniversitesi; 2018.

35. Zhang Y, Zhang Y, Zou S, Cao Y. Relationship between domestic violence and postnatal depression among pregnant Chinese women. International Journal of Gynecology and Obstetrics. 2012; 116: 26-30.

36. Kornfeld BD, Bair-Marrit MH, Frosch E, Solomon BS. Postpartum depression and intimate partner violence in urban mothers: Co-Occurrence and child healthcare utilization. The Journal of Pediatrics. 2012; 161(2): 348-353.

37. Oram S, Trevillion K, Feder G, Howard LM. Prevalence of experiences of domestic violence among psychiatric patients: systematic review. Br J Psychiatry. 2013; 202(2): 94-99. 